\title{
PEMANFAATAN NILAI KEJUJURAN DALAM CERPEN SEBAGAI BAHAN AJAR BERBASIS PENDIDIKAN KARAKTER
}

\author{
Umar Mansyur \\ Fakultas Sastra, Universitas Muslim Indonesia \\ umar.mansyur@umi.ac.id
}

\begin{abstract}
Abstrak
Karya sastra dapat membentuk kepribadian karena di dalamnya memuat amanat tentang moral, mengembangkan imajinasi dan kreativitas siswa. Pembelajaran sastra di sekolah, khususnya cerpen, bertujuan untuk menanamkan, menumbuhkan, dan mengembangkaan kepekaan kepada siswa terhadap masalah-masalah dunia, pengenalan dan rasa hormat terhadap tata nilai, baik dalam konteks individu maupun sosial, yang kesemuanya itu sangat relevan dengan muatan yang terdapat dalam kurikulum pendidikan karakter saat ini. Banyak nilai moral yang terkandung dalam sebuah cerpen. Manusia akan bertindak sesuai dengan nilai yang diyakininya. Semakin kuat nilai yang dipilih semakin kuat pula pengaruh nilai tersebut terhadap kehidupannya. Salah satunya adalah nilai kejujuran. Nilai kejujuran dalam cerpen dapat menjadi pondasi dalam mempelajari nilai moral yang lain. Nilai tersebut juga selaras dengan pendidikan karakter yang sedang gencar digalakkan oleh pemerintah dan tenaga pendidik. Pemanfaatan nilai kejujuran dalam cerpen dapat dijadikan sebagai alternatif bahan ajar yang berbasis pendidikan karakter.
\end{abstract}

Kata Kunci : Nilai kejujuran cerpen, bahan ajar, pendidikan karakter.

\section{PENDAHULUAN}

Sistem Pendidikan Nasional dalam Undang-Undang Nomor 20 tahun 2003 menjelaskan bahwa pendidikan nasional berfungsi mengembangkan kemampuan dan membentuk karakter serta peradaban bangsa yang bermartabat dalam rangka mencerdaskan kehidupan bangsa. Selanjutnya, dijelaskan pula bahwa pendidikan nasional bertujuan untuk mengembangkan potensi peserta didik agar menjadi manusia yang beriman dan bertakwa kepada Tuhan Yang Maha Esa, berakhlak mulia, sehat, berilmu, cakap, kreatif, mandiri, dan menjadi warga negara yang demokratis serta bertanggung jawab.

Salah satu cara yang dapat dilakukan untuk menanamkan pendidikan karakter adalah melalui pembelajaran apresiasi sastra. Pembelajaran apresiasi sastra dapat dijadikan sebagai media untuk menumbuhkan nilai-nilai moral. Sesuai dengan definisi apresiasi sastra yaitu kegiatan menggauli cipta sastra dengan sungguh-sungguh hingga tumbuh pengertian, penghargaan, kepekaan pikiran kritis, dan kepekaan perasaan yang 
baik terhadap cipta sastra, diharapkan para siswa dapat menanamkan nilai-nilai moral dan mengambil nilai-nilai yang positif dalam karya sastra tersebut.

Pembelajaran sastra di sekolah, khususnya cerpen, bertujuan untuk menanamkan, menumbuhkan, dan mengembangkaan kepekaan kepada siswa terhadap masalah-masalah dunia, pengenalan dan rasa hormat terhadap tata nilai, baik dalam konteks individu maupun sosial, yang kesemuanya itu sangat relevan dengan muatan yang terdapat dalam kurikulum pendidikan karakter saat ini. Melalui pembelajaran cerpen, siswa dapat lebih tanggap dalam konteks pembelajaran apapun, dan juga dapat lebih tanggap dalam kehidupan sosialnya.

Cerita pendek atau yang biasa disingkat cerpen adalah sebuah karya sastra yang berbentuk prosa. Cerpen dapat menampilkan persoalan manusia dengan liku-liku kehidupannya. Menurut Nurgiantoro (1995), karena bentuknya yang pendek, cerpen menuntut penceritaan yang serba ringkas, tidak sampai pada detil-detil khusus yang kurang penting yang lebih bersifat memperpanjang cerita.

Banyak nilai moral yang terkandung dalam cerpen. Manusia akan bertindak sesuai dengan nilai yang diyakininya. Semakin kuat nilai yang dipilih semakin kuat pula pengaruh nilai tersebut terhadap kehidupannya. Salah satunya adalah nilai kejujuran. Nilai kejujuran termasuk dalam satu nilai yang terkandung dalam pendidikan karakter. Hal ini sejalan dengan pendapat Sudarajat (2002) bahwa pendidikan karakter adalah suatu sistem penanaman nilai-nilai karakter kepada warga sekolah yang meliputi komponen pengetahuan, kesadaran atau kemauan, dan tindakan untuk melaksanakan nilai-nilai tersebut.

Lebih lanjut Santrock (2007) juga menegaskan bahwa pola perkembangan manusia dihasilkan dari proses kognitif dan proses sosial emosi. Dengan membaca sastra, dapat mengolah pola pikir dan menambah kosakata serta mempengaruhi pola pikir dan intelegensia. Sebuah karya sastra dikatakan baik untuk dikonsumsi oleh masyarakat pembaca jika di dalamnya terkandung nilai-nilai yang positif. Demikian juga cerita pendek, akan baik dibaca oleh pembaca jika di dalamnya mengandung nilainilai yang mampu menjadi suri teladan bagi pembacanya. Oleh karena itu, cerpen dapat digunakan sebagai alternatif bahan ajar untuk mengajarkan nilai kejujuran yang berbasis pendidikan karakter. 


\section{NILAI KEJUJURAN CERPEN}

\section{Bentuk dan Fungsi Nilai Kejujuran}

Setiap cerpen mempunyai nilai moral yang disampaikan di dalamnya. Nilai moral tersebut menjadi dasar panduan hidup manusia dalam kehidupan pribadinya. Untuk itu, kejujuran adalah salah satu nilai moral yang patut dipelajari oleh siswa di sekolah. Nilai kejujuran akan mendorong siswa untuk melakukan hal yang sesuai dengan norma dan kebenaran.

Sebuah cerpen mempunyai nilai yang ingin disampaikan oleh pengarangnya. Nilai dirasakan dalam diri masing-masing sebagai daya pendorong atau prinsip-prinsip, yang menjadi pedoman dalam hidup (Kaswardi, 1993). Nilai kejujuran yang ada dalam cerpen juga memiliki kekuatan untuk menjadikan pembacanya mempunyai prinsip yang benar ketika pembaca mampu menemukan nilai kejujuran dalam cerpen tersebut.

Bentuk nilai kejujuran dapat menggambarkan fungsi nilai kejujurannya. Fungsi nilai kejujuran dalam cerpen juga bermacam-macam. Nilai kejujuran dapat berfungsi sebagai penguat karakter tokoh, mengakhiri cerita, memberikan klimaks cerita dan mengawali konflik.

Bentuk nilai kejujuran pada cerpen di antaranya adalah nilai kejujuran dalam menyatakan perasaan. Kejujuran dalam menyatakan perasaan adalah tema yang banyak diminati oleh remaja. Hal ini disebabkan oleh perkembangan remaja yang mulai tertarik pada lawan jenis dan sudah menginginkan daya tarik terhadap lawan jenis. Hal ini dipertegas oleh Hurlock (1994) bahwa remaja laki-laki ataupun perempuan akan mengembangkan sikap yang baru terhadap lawan jenis dan mengembangkan minat terhadap kegiatan yang melibatkan laki-laki dan peremuan.

Selain itu, menurut Pratiwi (2012) bentuk kejujuran yang ada dalam cerpen adalah kejujuran menyatakan fakta atau informasi yang ada, kejujuran dalam bentuk sikap, dan kejujuran dalam bentuk amanat. Kejujuran yang berbentuk amanat sering inilah yang sering digunakan sebagai bahan ajar karena pembaca dapat secara langsung menangkap amanat yang disampaikan pengarang dalam karya sastranya.

\section{Penggambaran Nilai Kejujuran}

Menurut Nurgiantoro (1995), bentuk penyampaian pesan moral secara tidak langsung biasanya tersirat dalam cerita dan berupa koherensi antara unsur-unsur cerita seperti tokoh, perwatakan, dan alur. Penggambaran nilai kejujuran dalam cerpen 
dituangkan dalam: (1) penggambaran nilai kejujuran melalui dialog, (2) penggambaran nilai kejujuran melalui tokoh, dan (3) penggambaran nilai kejujuran melalui deskripsi pengarangnya. Penggambaran nilai-nilai kejujuran tersebut mampu merangsang siswa untuk menemukan sendiri nilai kejujuran yang terkandung dalam cerpen.

Penggambaraan nilai kejujuran dalam cerpen juga dapat mengajarkan siswa tentang variasi penggambaran nilai kehidupan. Siswa dapat menemukan sendiri amanat yang terkandung dalam cerpen atau siswa dapat membaca sebuah nilai yang sudah dipaparkan oleh pengarang. Ada beberapa pembaca yang menyukai penggambaran nilai secara langsung karena dirasa lebih mudah dipahami. Selain itu, ada juga pembaca yang lebih menyukai penggambaran nilai secara tidak langsung karena pembaca dapat menggunakan imajinasinya dalam menemukan nilai tersebut.

Penggambaran nilai kejujuran ini dapat membantu pembaca untuk memahami nilai kejujuran yang disampaikan pengarang dalam karya sastranya. Penggambaran nilai kejujuran melalui dialog memang lebih mudah dibuat oleh pengarang karena biasanya kejujuran adalah sebuah pengakuan yang dilakukan oleh tokoh dalam cerita. Selain itu, penggambaran nilai kejujuran melalui tokoh termasuk dalam penggambaran nilai secara tidak langsung. Pengarang menginginkan pembaca menjadi pembaca yang kritis sehingga bisa menemukan amanat yang ingin pengarang sampaikan.

Penggambaran nilai yang terakhir adalah penggambaran nilai kejujuran melalui deskripsi pengarang. Penggambaran nilai kejujuran yang seperti ini termasuk dalam penggambaran secara langsung. Pengarang mendeskripsikan nilai kejujuran dengan bahasa yang lugas sehingga pembaca dapat memahaminya dengan mudah.

\section{BAHAN AJAR BERBASIS PENDIDIKAN KARAKTER}

Ada delapan belas muatan pendidikan karakter yang terintegrasi dalam kurikulum pendidikan di sekolah, antara lain: (1) religius, (2) jujur, (3) toleransi, (4) disiplin, (5) kerja keras, (6) kreatif, (7) mandiri, (8) demokratis, (9) rasa ingin tahu, semangat kebangsaan, (10) cinta tanah air, (11) menghargai prestasi, (12) bersahabat, (13) komunikatif, (14) cinta damai, (15) gemar membaca, (16) peduli lingkungan, (17) peduli sosial,dan (18) tanggung jawab.

Muatan pendidikan karakter di sekolah dimanifestasikan dalam pembelajaran menggunakan bahan ajar. Bahan ajar merupakan bahan atau materi pembelajaran yang disusun secara sistematis yang digunakan guru dan siswa dalam kegiatan belajar 
mengajar. Bahan ajar untuk peserta didik tingkat menengah pertama membutuhkan bahan ajar yang dapat mengajarkan nilai-nilai perkembangan kepribadian kepada peserta didik. Nilai-nilai perkembangan dalam pembelajaran tersebut terkumpul dalam suatu wadah yang disebut pendidikan karakter (Kemendiknas, 2008).

Pendidikan karakter sangat penting diterapkan sejak anak usia sekolah menengah pertama. Hal ini disebabkan para siswa yang melewati masa remajanya ditandai dengan terjadinya pergolakan emosi yang diiringi pertumbuhan fisik yang pesat dan pertumbuhan psikis yang bervariasi. Di masa kini, remaja mudah terpengaruh oleh lingkungan dan sebagai akibatnya akan muncul kekecewaan dan penderitaan, meningkatnya konflik dan pertentangan, impian dan khayalan, pacaran dan percintaan, keterasinagan dari kehidupan dewasa dan norma kebudayaan (Gunarsa, 1986). Di masa seperti saat ini, siswa butuh diberi bimbingan agar lebih mengerti nilai-nilai perkembangan yang mereka butuhkan untuk terjun dalam kehidupan sosial. Masa remaja adalah periode di mana seseorang mulai bertanya-tanya mengenai berbagai fenomena yang terjadi di lingkungan sekitarnya sebagai dasar bagi pembentukan nilai diri mereka.

Selanjutnya, karya sastra yang baik memiliki beberapa kriteria, salah satunya adalah memberikan pembelajaran kepada pembacanya. Semua karya sastra memiliki tujuan yang ingin disampaikan oleh pengarangnya. Setiap tujuan pengarang akan diresapi dan dijadikan pedoman atau hanya dibiarkan saja oleh pembaca. Kaswardi (1993) berpendapat bahwa pembaca cenderung memilih bacaan yang sesuai dengan nilai-nilai pembaca itu sendiri. Pembaca akan lebih menyukai bacaan yang sesuai dengan pemikiran atau minatnya. Pembaca yang menyukai poltik akan lebih memilih bacaan yang membahas tentang politik dan pembaca yang menyukai sastra akan lebih memilih bacaan yang bergenre sastra.

Cerpen memiliki kelebihan menjadi karya sastra yang dapat diambil amanat yang menjadi tujuan pengarang. Lebih lanjut Kaswardi (1993) mengemukakan bahwa orang bertindak berdasarkan nilai yang diyakininya. Semakin kuat nilai yang dipilih akan semakin kuat pengaruh nilai tersebut terhadap kehidupannya. Nilai kejujuran dapat menjadi pondasi untuk mempelajari nilai moral yang lain. Nilai tersebut juga diselaraskan dengan pendidikan karakter yang sedang gencar digalangkan oleh pemerintah dan tenaga pendidik. 
Cerpen-cerpen yang dianalisis cara penggambaran nilai, bentuk, dan fungsi nilainya dapat dicermati nilai kejujurannya dengan cara menganalisis bahasa yang digunakan, keruntutan ceritanya, pengaruh terhadap pembaca, dan amanat yang terkandung di dalamnya. Beberapa analisis tersebut dapat membantu untuk menemukan kemungkinan pemanfaatan nilai kejujuran untuk dijadikan alternatif bahan ajar berbasis pendidikan karakter.

\section{PENUTUP}

Muatan pendidikan karakter di sekolah dimanifestasikan dalam pembelajaran menggunakan bahan ajar. Bahan ajar untuk peserta didik membutuhkan materi pembelajaran yang dapat mengajarkan nilai-nilai perkembangan kepribadian peserta didik. Nilai-nilai perkembangan dalam pembelajaran tersebut terkumpul dalam suatu wadah yang disebut pendidikan karakter.

Sebuah karya sastra dikatakan baik untuk dikonsumsi oleh pembaca jika di dalamnya terkandung nilai-nilai yang positif. Demikian halnya dengan cerpen, akan baik dibaca oleh pembaca jika di dalamnya mengandung nilai-nilai yang mampu menjadi suri teladan bagi pembacanya. Oleh karena itu, cerpen dapat digunakan sebagai alternatif bahan ajar untuk mengajarkan nilai kejujuran yang berbasis pendidikan karakter.

\section{DAFTAR PUSTAKA}

Gunarsa, D. 1986. Psikologi Perkembangan Anak dan Remaja. Jakarta: PT. BK Gunung Mulia.

Hurlock, Elizabeth.B. 1994. Psikologi Perkembangan. Jakarta: Erlangga.

Kaswardi, K. 1993. Pendidikan Nilai Memasuki Tahun 2000. Jakarta: PT Grasindo. Kemdiknas. 2008. Sosialisasi KTSP: Pengembangan Bahan Ajar. Jakarta: Kemdiknas. Khan, Y. 2010. Pendidikan Karakter Berbasis Potensi Diri: Mendongkrak Kualitas Pendidikan. Yogyakarta: Pelangi Publishing.

Moleong, L.J. 1988. Metode Penelitian Kualitatif. Jakarta: Depdikbud.

Nurgiyantoro. 1995. Teori Pengkajian Fiksi. Yogyakarta: Gajahmada University Press. Priyatni, Endah Tri. 2014. Desain Pembelajaran Bahasa Indonesia dalam Kurikulum 2013. Jakarta: Bumi Aksara.

Rahmanto, B. 1988. Metode Pengajaran Sastra. Yogyakarta: Kanisius.

Santrok, John, W. 2007. Life Span Development: Perkembangan Masa Hidup. Jakarta: Erlangga. 